\title{
Bioecological Characteristics of the Flora of the Territories Adjacent to the Springs of Western Kazakhstan
}

\author{
Guldana Z. Idrissova ${ }^{1}$, kairgalieva_guldana@mail.ru \\ Irina V. Sergeeva ${ }^{2}$, https://orcid.org/0000-0001-6824-1597; ivsergeeva@mail.ru \\ Ekatherina N. Shevchenko ${ }^{2}$, https://orcid.org/0000-0002-6474-5242; en-shevchenko@mail.ru \\ Albina L. Ponomareva ${ }^{2}$, https://orcid.org/0000-0001-7423-7084; alb67na@mail.ru \\ Kazhmurat M. Akhmedenov ${ }^{3}$, https://orcid.org/0000-0001-7294-0913; kazhmurat78@mail.ru \\ ${ }^{1}$ Western Kazakhstan Agrarian-Technical University named after Zhangir Khan \\ 51 Zhangir Khan St., Uralsk 090009, Kazakhstan \\ ${ }^{2}$ Saratov State Agrarian University named after N. I. Vavilov \\ 1 Teatralnaya Sq., Saratov 410012, Russia \\ ${ }^{3}$ Makhambet Utemisov West Kazakhstan State University \\ 162 N. Nazarbayev Avenue, Uralsk 090009, Kazakhstan
}

Received 22 December 2018, revised 18 March 2019, accepted 11 May 2019

\begin{abstract}
Idrissova G. Z., Sergeeva I. V., Shevchenko E. N., Ponomareva A. L., Akhmedenov K. M. Bioecological Characteristics of the Flora of the Territories Adjacent to the Springs of Western Kazakhstan. Povolzhskiy Journal of Ecology, 2019, no. 4, pp. 419 - 431. DOI: https://doi.org/ $10.35885 / 1684-7318-2019-4-419-431$
\end{abstract}

This article is an open access article distributed under the terms and conditions of the Creative Commons Attribution 4.0 License

The data of floristic studies of 40 spring tracts of the Mangistau, Aktobe, Atyrau and West Kazakhstan regions of the Western Region of the Republic of Kazakhstan are presented. We have found that the studied flora is represented by 252 species, 167 genera and 55 families belonging to Equisetophyta, Pinophyta, and Magnoliophyta divisions. Taxonomic characterization of the flora showing the predominance of the Asteraceae and Poaceae families is provided. The predominance of perennial herbaceous plants in the flora of spring tracts was identified by the system of I. G. Serebryakov's life forms. The predominance of steppe plants and weeds was revealed. Horological analysis showed the leading set of species with the Eurasian range type. Ecological characteristics highlighted the predominance of xerophytes and mesotrophic plants. 20 protected plant species listed in the Red Data Book of the Russian Federation and the Red Data Book of the Republic of Kazakhstan were identified. Analysis of the distribution of plants in the areas adjacent to the springs identified four grades of occurrence, namely: common species - 7; uncommon species 17; rare species -100 ; and very rare species -128 . The most common species found within the spring tract territories are related to weeds, such as Tripleurospermum perforatum (Merat) M. Lainz, Polygonum aviculare L., Taraxacum officinale Wigg., Lappula squarrosa (Retz.) Dumort., Plantago major L., Arctium lappa L., Xanthium strumarium L., Capsella bursa-pastoris (L.) Medik., Chenopodium album L., Convulvus arvensis L., Poa annua L., Bromus squarrosus L., Elytrigia repens (L.) Nevski. The Jaccard index $\left(K_{\mathrm{j}}\right)$ for the analyzed floras in pairwise comparison varies from 0.02 to 0.5 , which shows the extreme heterogeneity of the specific composition.

Keywords: flora, springs, tract, biomorphological and ecological characteristics, Western Kazakhstan.

DOI: https://doi.org/10.35885/1684-7318-2019-4-419-431

(C) Idrisova G. Z., Sergeeva I. V., Shevchenko E. N., Ponomareva A. L., Akhmedenov K. M., 2019 


\section{INTRODUCTION}

There are about 200 springs in Western Kazakhstan (Akhmedenov, 2015). Springs in the steppe zones are very important sources of water supply for small settlements; they also determine the recreational potential and floral diversity of the territory. The flora of the territories adjacent to the spring outlets is influenced by various factors including the location of the spring, the distance from roads and settlements, the physical and chemical composition of water, etc.

Extreme environmental conditions of Western Kazakhstan result in high endemism of flora. In addition, the study area is subject to anthropogenic impact and, as a result, there is a problem of conservation of species biodiversity (Mamysheva, Darbaeva, 2012). Many spring tracts are a place of recreation for the local population; this fact naturally affects the flora and vegetation. Currently, the features of recreational changes in flora and plant communities and their components are increasingly attracting the attention of researchers (Davidenko, 2016).

Floristic composition serves as an indirect indicator of the state of the spring tract and the degree of its disturbance (Sivohip, Kalmykova, 2007). Some springs become the centers of unique plant communities where rare species of plants grow (Zhantasova, Akhmedenov, 2012; Idrisova et al., 2018). The quality of the environment can be judged by the state of rare species. Indeed, rare species of flora constitute the most fragile component of biodiversity and serve as a good indicator of any changes in such ecological parameter. West Kazakhstan region has a unique set of landscape complexes (Myrzagalieva, Stanis, 2016). Springs play a leading role in the process of maintaining the stability of the surrounding terrestrial biocenoses, as well as in the formation of natural landscapes.

Some springs contain highly mineralized water and therapeutic mud. As a result, these tracts become involved in unorganized balneological activities that affect not only the flora but also the mineral mud resources. Unregulated utilization and absence of restoration measures will bring such mineral mud resources to extinction (in fact, such thing already happened in Sol-Iletsk). Big spring tracts, such as Ashchytuzbulak, Tilepbulak, and Tuzdybulak are visited by up to 100 people per day (Akhmedenov et al., 2017). These areas are home to rare petrophytes (e.g., Eremurus inderiensis (Stev.) Regel, Ixiolirion tataricum (Pall.) Schult. \& Schult. fil., Leontice incerta Pall, etc.) that undergo extreme anthropogenic pressure.

Foreign spring studies also show the importance of conservation of spring tracts, as they provide habitat for endemic species (Rosenau et al., 1977; Fensham, Fairfax, 2003). For example, Fensham (1998) who studied springs in the Dawson river valley, Queensland, confirms the presence of rare and isolated plant communities in the coastal area of springs, and therefore the vulnerability of rare plant species and their importance.

Many springs have unusual geomorphological features and contain rare species of flora, endemic invertebrates and fish (Ponder, 2002). Due to their ecological simplicity, they have significant potential for evolutionary and ecological research. Over the past hundred years, many springs have disappeared, and most of the remaining ones are threatened with degradation.

In this regard, the study of the flora of the territories adjacent to the springs located in Western Kazakhstan is undoubtedly relevant, so this study was devoted to this topic. 


\section{BIOECOLOGICAL CHARACTERISTICS OF THE FLORA}

\section{MATERIAL AND METHODS}

During the field seasons of 2015-2017, we studied the flora of 40 spring tracts of Mangistau, Aktobe, Atyrau and West Kazakhstan regions of the Western Region of the Republic of Kazakhstan and collected about 1000 herbarium sheets.

The study of flora was carried out via the route method. We studied the vascular plants growing within the areas of spring tracts $\left(400 \mathrm{~m}^{2}\right)$. Collection and drying of herbarium samples were carried out according to the standard method (Skvortsov, 1977).

The species identification for collected plants was carried out according to the following keys: Catalogue of plants of the West Kazakhstan region (Darbaeva, Chukalina, 2011); flora of the middle zone of the European part of the USSR (Mayevsky, 1964, 2006). Species names are given according to the summary of S. K. Cherepanov (1995). In the course of the analysis, the plants were distributed by geographical longitude groups in accordance with the works of A. I. Tolmachev $(1974,1986)$ and T. I. Plaksina (2001). Identification of plant life forms was performed in accordance with systems proposed by C. Raunkiaer (1934) and I. G. Serebryakov (1962, 1964). Cenomorphic composition of the flora was determined in accordance with recommendations of N. M. Matveev (2006). Data visualization was performed using the Microsoft Office Excel 2007 graphical editor. Comparison of the studied floras was performed via Jaccard indices $(K j)$ calculated in Microsoft Excel using ExStatR software (https://ib.komisc.ru/rus/database/exstatr).

\section{RESULTS}

The flora of the territories adjacent to 40 springs within the boundaries of four regions of Western Kazakhstan is represented by 252 species, 167 genera, and 55 families. The flora is represented by three divisions - Equisetophyta, Pinophyta, and Magnoliophyta. The Equisetophyta division is represented by 4 species (Equisetum arvense L., E. fluviatile L., E. pratense Ehrh., E. sylvaticum L.), while Pinophyta division is represented by a single species (Ephedra distachya L.). Most of the plant species (247) belong to the Magnoliophyta division with 58 species of 36 genera and 11 families belonging to Liliopsida class species, and 189 species of 136 genera and 43 families belonging to Magnoliopsida class. Thus, in the number of species, genera and families, the Magnoliopsida class dominates over Liliopsida class.

The Asteraceae and Poaceae families predominate in the number of presented species (Table 1).

Among the other families, the largest number of species belong to Rosaceae, Lamiaceae, Fabaceae, Chenopodiaceae, Liliaceae, Polygonaceae, Brassicaceae, and Scrophulariaceae families. The species of these families include wild species of fruit and berry plants (Rosaceae family) that are mesophytes of moist habitats. The following xerophytic species (of Chenopodiaceae, Fabaceae, Scrophulariaceae and Brassicaceae families) and ephemeroids (Liliaceae family) characteristic of this climatic zone have been noted: Rhinopetalum karelinii Fisch. Ex D. Don, Tulipa gesneriana L., T. greigii Regel, T. biebersteiniana Schult. \& Schult. fil.) common for steppe landscapes where the studied spring tracts are located; we also found hygrophytes of the Polygonaceae family (Rumex confertus Willd., R. crispus L. Persicaria amphibian (L.) S. F. Gray, P. hydropiper (L.) Spach, Bistorta major S. F. Gray). 
G. Z. Idrissova, I. V. Sergeeva, E. N. Shevchenko et al.

Table 1. A list of primary flora families of territories agjacent to the springs of Western Kazakhstan

\begin{tabular}{l|c|c|c|c}
\hline \multicolumn{1}{c|}{ Family } & $\begin{array}{c}\text { Number of } \\
\text { genera }\end{array}$ & $\begin{array}{c}\text { The percentage to the total } \\
\text { number of genera, \% }\end{array}$ & $\begin{array}{c}\text { Number of } \\
\text { species }\end{array}$ & $\begin{array}{c}\text { The percentage to the total } \\
\text { number of species, \% }\end{array}$ \\
\hline Asteraceae & 24 & 13.95 & 43 & 17.06 \\
\hline Poaceae & 22 & 12.79 & 34 & 13.49 \\
\hline Rosaceae & 12 & 6.98 & 18 & 7.14 \\
\hline Lamiaceae & 12 & 6.98 & 16 & 6.35 \\
\hline Fabaceae & 10 & 5.81 & 13 & 5.16 \\
\hline Chenopodiaceae & 8 & 4.65 & 13 & 5.16 \\
\hline Liliaceae & 4 & 2.33 & 8 & 3.17 \\
\hline Polygonaceae & 5 & 2.91 & 8 & 3.17 \\
\hline Brassicaceae & 7 & 4.07 & 7 & 2.78 \\
\hline Scrophulariaceae & 5 & 2.91 & 7 & 66.27 \\
\hline Total & 109 & 63.37 & 167 & 33.73
\end{tabular}

The remaining families are arranged in the following order: 6 species of the studied flora belong to Caryophyllaceae family, while 5 species belong to Salicaceae family. Three families - Apiaceae, Equisetaceae and Cyperaceae - are represented by 4 species. The Geraniaceae, Ranunculaceae, Boraginaceae and Typhaceae families are represented by 3 species. Families represented by one or two species make up 20.2\% of the total number of species. Species saturation index of the studied flora families equals 4.5.

The studied flora includes 172 genera. The most prominent is Artemisia genera represented by 12 species. The second place is occupied by two genera, Equisetum and Poa, each represented by 4 species. There are 14 genera represented by 3 species (Bromopsis, Typha, Stipa, Agropyron, Tulipa, Salix, Rumex, Persicaria, Atriplex, Chenopodium, Potentilla, Achillea, Centaurea, Tanacetum); $90 \%$ of (the total number of) genera include 1-2 species, in $76 \%$ of cases one genus contains one species. Species saturation index for genera equals 1.5 .

The biomorphological structure of flora is represented by life forms (LF) that adapt very well to environmental conditions and serve as units of ecological classification of plants. According to the system proposed by I. G. Serebryakov (1964), the studied species are represented by 10 LF - trees, shrubs, half-shrubs, dwarf shrubs, dwarf halfshrubs, perennial-biennial-annual grasses and annual or biennial grasses (Table 2).

Perennial herbaceous plants (154 species) including ecologically flexible longrooted grasses $(22.62 \%)$, rod-rooted $(13.49 \%)$, and short-rooted $(13.10 \%)$ species form the basis of the flora of spring tracts. To a lesser extent, bulbous, turf-rooted, loosely rooted, racemous-rooted and dense-rooted perennial grasses are common. The flora includes two notable racemous-rooted species (Leontice vesicaria Willd, Phlomis tuberosa L., Scrophylaria nodosa L.) and one perennial bulbotuberiferous spieces - Gladiolus imbricatus L.

The group of annual plants is represented by 27 species (10.71\%) from the following families: Chenopodiaceae -9 species, Poaceae -2 species, Asteraceae -3 species, Polygonaceae 2 species, Brassicaceae - 3 species, Amaranthaceae - 1 species, Urticaceae -1 species, Cannabaceae -1 species, Lamiaceae -1 species, Rubiaceae -1 species, Fumariaceae -1 species, Orobanchaceae -1 species, Geraniaceae -1 species. The annual plant composition includes approximately 67\% of weed species (Echinochloa 


\section{BIOECOLOGICAL CHARACTERISTICS OF THE FLORA}

crusgalli (L.) Beauv., Amaranthus retroflexus L., Urtica urens L., Polygonum aviculare L., Atriplex tatatrica L., Chenopodium album L., Chenopodium glaucum L., Chenopodium urbicum L., Cannabis sativa L., Fumaria officinalis L., Capsella bursa-pastoris (L.) Medik., Descurainia sophia (L.) Webb ex Prantl, Galeopsis tetrahit L., Ambrosia artemisiifolia L., Conyza canadensis (L.) Cronq., Xanthium strumarium L., Orobanchec oerulescens Steph., Galium aparine L.), the presence of which indicates of a violation of the structure of the flora.

Table 2. Distribution of flora species growing at the territories adjacent to the springs of Western Kazakhstan by life forms (as described by I. G. Serebryakov, 1964)

\begin{tabular}{|c|c|c|}
\hline Life forms & $\begin{array}{l}\text { Number of } \\
\text { species }\end{array}$ & $\begin{array}{c}\text { The percentage to the total } \\
\text { number of species, } \%\end{array}$ \\
\hline Trees & 11 & 4.37 \\
\hline Shrubs & 20 & 7.94 \\
\hline Half-shrubs & 7 & 2.78 \\
\hline Dwarf shrubs & 1 & 0.40 \\
\hline Dwarf half-shrubs & 14 & 5.56 \\
\hline Perennial herbs, including: & & \\
\hline long-rooted & 57 & 22.62 \\
\hline tap-rooted & 34 & 13.49 \\
\hline short-rooted & 33 & 13.10 \\
\hline bulbous & 7 & 2.78 \\
\hline cespitose-rooted & 6 & 2.38 \\
\hline loosely-rooted (cespitose) & 4 & 1.59 \\
\hline racemous-rooted & 6 & 2.38 \\
\hline dense-rooted (cespitose) & 3 & 1.19 \\
\hline bulbous-rooted & 3 & 1.19 \\
\hline bulbotuberiferous & 1 & 0.40 \\
\hline Lianas & 1 & 0.40 \\
\hline Annual plants & 27 & 10.71 \\
\hline Annual or biennial plants & 5 & 1.98 \\
\hline Biennial plants & 12 & 4.76 \\
\hline Total & 252 & 100.0 \\
\hline
\end{tabular}

Biennial plants make up $4.76 \%$ of the total species and are represented by Apiaceae, Solanaceae, Asteraceae, Poaceae, Caryophyllaceae and Fabaceae families. Annual or biennial plants make up $1.98 \%$ of the total species.

The trees $(4.37 \%)$ are represented by the followings families: Salicaceae -5 species, Betulaceae -2 species, Moraceae -1 species, Fagaceae -1 species, Elaeagnaceae 1 species, Oleaceae -1 species.

The shrub group (20 species) is dominated by plants of the Rosaceae family (Crataegus ambigua C. A. Mey. ex A. Beck, C. laevigata (Poir.) D.C., Spiraea crenata L., S.salicifolia L., Rubus idaeus L., Rosa canina L., R. glabrifolia C.A. Mey. ex Rupr., Amygdalus nana L., Cerasus fruticosa Pall., Prunus spinosaL.,) и Fabaceae (Astragalus brachylobus Fisch., Caragana frutex (L.) K. Koch, C. grandiflora (M. Bieb.) DC., Alhagi pseudalhagi (Bieb.) Fisch.). Half-shrubs are represented by 7 species: Artemisia abrotanum L., Limonium suffruticosum (L.) O. Kuntze, Krascheninnikovia ceratoides (L.) Gueldenst., Halocnemum strobilaceum (Pall.) Bieb., Lepidium meyeri Claus, Rubus 
caesius L., Solanum dulcamara L. The dwarf half-shrubs are represented by the following 14 species: Anabasis salsa (C.A. Mey.) Benth. Ex Volkens, Atriplex cana C. A. Mey, Kochia prostrata (L.) Schrad., Silene cretacea Fisch. ex Spreng., Thymus marschallianus Willd., Scabiosa isetensis L., Anthemis trotzkiana Claus, Artemisia santonica L., Artemisia salsoloides Willd., A. Pauciflora Web., A. Gurganica (Krasch.) Filat., Artemisia lercheana Web. The flora contains a single dwarf shrub species Ephedra distachya L. - and one liana species - Humulus lupulus L.

Using C. Raunkiaer (1934) system to study vascular plant life forms present in the flora, we identified 6 life forms (Table 3).

Table 3. Distribution of flora species growing at the territories adjacent to the springs of Western Kazakhstan by life forms (as described by Raunkiaer)

\begin{tabular}{l|c|c}
\hline \multicolumn{1}{c|}{ Life forms } & $\begin{array}{c}\text { Number } \\
\text { of species }\end{array}$ & $\begin{array}{c}\text { The percentage to the } \\
\text { total number of vascu- } \\
\text { lar plant species, \% }\end{array}$ \\
\hline Hemicryptophytes & 133 & 52.78 \\
\hline Cryptophytes & 34 & 13.49 \\
\hline Phanerophytes & 31 & 12.30 \\
\hline Therophytes & 26 & 10.32 \\
\hline Chamephytes & 23 & 9.13 \\
\hline Therophytes or hemicriptophytes & 5 & 1.98 \\
\hline Total & 252 & 100.00
\end{tabular}

The dominant life forms are hemicryptophytes $(52.78 \%)$ represented by Asteraceae, Poaceae, Fabaceae, and Rosaceae families. Dominant cryptophytes $(13.49 \%)$ include species from Liliaceae, Poaceae, and Equisetaceae families. Phanerophytes $(12.30 \%)$ are represented by Salicaceae, Betulaceae, Polygonaceae, Grossulariaceae, Rosaceae, Fabaceae, Oleaceae, and Rhamnacea families. Therophytes $(10.32 \%)$ belong to Chenopodiaceae, Asteraceae, and Poaceae families. Notable chamephytes $(9.13 \%)$ belong to Caryophyllaceae and Chenopodiaceae families. Plants that can be either therophytes or hemicriptophytes made up to $1.98 \%$ of the total number of species.

Species of the studied flora belong to six main phytocenotic groups and to 19 cenomorphs (Table 4).

The largest number of species (73) belongs to the group of steppe plants. Another numerous group is the weed group of plants that includes 54 weed, meadow weed, forest weed, and edge weed species, indicating of an anthropogenic impact on the composition of the flora.

Forest (47 species) and aquatic (34 species) groups of plants that require sufficient moisture conditions, typical for territories adjacent to the springs, have a significant share within the flora composition. Aquatic group is represented by 24 coastal aquatic species, 4 marsh coast species and 6 meadow coast species. The flora contains meadow species (27), including a group of meadow coast plants that is a characteristic feature for the flora of the spring tracts. A total of 17 species belong to the arid group.

The chorological analysis allows establishing correlations between geographical elements of the composition of flora and species with the same spread (range) (Sinitsyna, 2013). The horological analysis revealed the heterogeneity of flora and identified 12 geographical longitudinal groups (Table 5). 


\section{BIOECOLOGICAL CHARACTERISTICS OF THE FLORA}

Table 4. Phytocenotic structure of flora growing at the territories adjacent to the springs of Western Kazakhstan

\begin{tabular}{l|c|c|c}
\hline \multirow{2}{*}{ Phytocenotic group } & Cenomorph type & $\begin{array}{c}\text { Number of } \\
\text { species }\end{array}$ & $\begin{array}{c}\text { The percentage to the total } \\
\text { number of species, \% }\end{array}$ \\
\hline \multirow{4}{*}{ Aquatic } & Helophytic & 24 & 9.52 \\
\cline { 2 - 4 } & Swamp coast & 4 & 1.59 \\
\cline { 2 - 4 } & Swamp and meadow & 6 & 2.38 \\
\cline { 2 - 4 } & Meadow & 18 & 7.14 \\
\hline \multirow{3}{*}{ Morest } & Meadow coast & 9 & 3.57 \\
\cline { 2 - 4 } & Forest & 13 & 5.16 \\
\cline { 2 - 4 } & Forest edge & 11 & 4.37 \\
\cline { 2 - 4 } & Meadow edge & 19 & 7.54 \\
\hline \multirow{3}{*}{ Steppe } & Steppe edge & 4 & 1.59 \\
\cline { 2 - 4 } & Steppe & 43 & 17.06 \\
\cline { 2 - 4 } & Steppe and semi-arid & 10 & 3.97 \\
\cline { 2 - 4 } & Meadow and steppe & 20 & 7.94 \\
\cline { 2 - 4 } & Weed & 36 & 14.29 \\
\cline { 2 - 4 } & Meadow weed & 11 & 4.37 \\
\cline { 2 - 4 } & Forest weed & 4 & 1.59 \\
\cline { 2 - 4 } & Edge weed & 3 & 1.19 \\
\hline \multirow{3}{*}{ Arid } & Steppe arid & 4 & 3.97 \\
\cline { 2 - 4 } & Semi-arid and arid & 10 & 1.19 \\
\cline { 2 - 4 } & Arid & 252 & 100.0 \\
\hline
\end{tabular}

The majority of identified species belong to Eurasian range group (57.94\% of the total number of species) represented by Poaceae, Liliaceae, Chenopodiaceae, Rosaceae, and Fabaceae families. Species with Holarctic range group (15.87\%) from Poaceae, Polygonaceae, and Salicaceae families are also dominant, which is natural, since the West Kazakhstan Region is located within the territory of the Holarctic Region (Takhtadzhyan, 1978). The third most frequent group is taken by the pluriregional geographical longitude group $(7.14 \%)$ formed by species from Poaceae, Asteraceae and Urticaceae families. The Asian (6.35\%), Euro-Siberian $(5.16 \%)$ and European $(3.17 \%)$ geographical groups are represented less. The smallest number of species belongs to the Eastern European, American, East European and Asian groups that range from 1.19 to $0.79 \%$. Mediterranean, Ancient Mediterranean and European American groups are represented by a single species $(0.40 \%$ each species $)$.

Table 5. Distribution of species of the studied flora by geographical longitudinal groups

\begin{tabular}{l|c|c}
\hline $\begin{array}{c}\text { Geographical } \\
\text { longitudinal group }\end{array}$ & $\begin{array}{c}\text { Number of } \\
\text { species }\end{array}$ & $\begin{array}{c}\text { The percentage to the } \\
\text { total number of vascu- } \\
\text { lar plant species, \% }\end{array}$ \\
\hline Eurasian & 146 & 57.94 \\
\hline Holarctic & 40 & 15.87 \\
\hline Pluriregional & 18 & 7.14 \\
\hline Asian & 16 & 6.35 \\
\hline Euro-Siberian & 13 & 5.16 \\
\hline European & 8 & 3.17 \\
\hline East-European & 3 & 1.19 \\
\hline American & 3 & 1.19 \\
\hline East European and Asian & 2 & 0.79 \\
\hline Mediterranean & 1 & 0.40 \\
\hline Ancient Mediterranean & 1 & 0.40 \\
\hline European and American & 1 & 0.40 \\
\hline \multicolumn{1}{c}{ Total } & 252 & 100.0
\end{tabular}


Species of the studied flora can be attributed to 9 ecological groups if we take into account the water availability parameter (Table 6).

Table 6. The distribution of species by hygromorphic type

\begin{tabular}{l|c|c}
\hline Hygromorphic types & $\begin{array}{c}\text { Number } \\
\text { of species }\end{array}$ & $\begin{array}{c}\text { The percentage to the total } \\
\text { number of species, \% }\end{array}$ \\
\hline Xerophytes & 69 & 27.38 \\
\hline Mesophytes & 53 & 21.03 \\
\hline Xeromesophyte & 51 & 20.24 \\
\hline Mesohygrophytes & 25 & 9.92 \\
\hline Mesoxerophytes & 18 & 7.14 \\
\hline Hygrophytes & 14 & 5.56 \\
\hline Ultrahydrophytes & 11 & 4.37 \\
\hline Hygrohydrophytes & 6 & 2.38 \\
\hline Hygromesophytes & 5 & 1.98 \\
\hline \multicolumn{1}{r|}{ Total } & 252 & 100.0
\end{tabular}

Xerophyte are the primary species $(27.38 \%)$ for arid zones. They are followed by mesophytes $(21.03 \%)$ and xeromesophytes $(20.24 \%)$ which is also understandable as the plants grow close to the springs. Intermediate groups - mesohygrophytes $(9.92 \%)$ and mesoxerophyte (7.14) - are located at the boundaries of hygromorphic range. The hygrophytic group is diverse: it contains hygrophytes (5.56\%), ultrahygrophytes (4.37\%), hygrohydrophytes (2.38\%) and hygromesophyte (1.98\%). According to nutrient status and salt conditions of soils and subsoils, the plants of the studied flora can be attributed to 7 ecological groups (Table 7).

Table 7. The distribution of species of the flora according to their trophic characteristics

\begin{tabular}{l|c|c}
\hline Trophic type & $\begin{array}{c}\text { Number of } \\
\text { species }\end{array}$ & $\begin{array}{c}\text { The percentage to the total } \\
\text { number of vascular plant } \\
\text { species, \% }\end{array}$ \\
\hline Mesotrophic & 128 & 50.79 \\
\hline Megatrophic & 69 & 27.38 \\
\hline Oligotrophic & 32 & 12.70 \\
\hline Halophyte & 15 & 5.95 \\
\hline Halomegatrophic & 6 & 2.38 \\
\hline Hyperhalophyte & 1 & 0.40 \\
\hline Parasite Total & 1 & 0.40 \\
\hline & 252 & 100.0
\end{tabular}

The dominant role of mesotrophic $(50.79 \%)$ and megatrophic $(27.38 \%)$ species in the structure of spring flora testifies to the predominance of soils and subsoils with sufficient and excessive amount of nutrients in the studied territory. $12.70 \%$ of plants are oligotrophic; these species are representatives of semi-arid and arid zones. The presence of a halophytic group

$(8.73 \%)$ in the studied flora indicates the presence of alkali soils and salt marshes. One parasitic plant - Orobanche coerulescens Steph - was found.

The substrate analysis revealed that the flora is composed from calciphiles, such as Atraphaxis frutescens (L.) C. Koch, Silene cretacea Fisch. ex Spreng., Lepidium meyeri Claus, Hedysarum grandiflorum Pall., Linaria cretacea Fisch. ex Spreng., Achillea nobilis L., Anthemis trotzkiana Claus, Artemisia salsoloides Willd, and psammophytes, such as Centaurea arenaria M. Bieb., Chondrilla juncea L., Helichrysum arenarium (L.) Moench, Achillea micrantha Willd., and Astragalus brachylobus Fisch.

Within the boundaries of Inder karst field (Ashchytuzbulak, Tilepbulak and Tuzdybulak springs) we discovered a number of rare petrophytes - Eremurus inderiensis (Stev.) Regel, Ixiolirion tataricum (Pall.) Schult. \& Schult. fil., Leontice incerta Pall., Rhinopetalum karelinii Fisch. ex D. Don, Dodartia orientalis L.

We also found 20 rare species of plants listed in the Red Book of the Russian Federation (2008) and the Red book of Kazakhstan (2006) on the territory of 12 springs (Idrisova et al., 2018). 


\section{BIOECOLOGICAL CHARACTERISTICS OF THE FLORA}

According to analysis of species distribution in the flora of the territories adjacent to the springs of Western Kazakhstan, we classified all species into four types based on their grade of occurrence, namely: common, uncommon, rare and very rare plants.

The most common are 7 species of plants: Tripleurospermum perforatum (Merat) M. Lainz, Polygonum aviculare L., Taraxacum officinale Wigg., Lappula squarrosa (Retz.) Dumort., Plantago major L., Trifolium pratense L., Plantago lanceolata L. These species mainly belong to weeds (with the exception of the last two, that are meadow and meadow-steppe species, respectively) and have been found within the territories of 8 to 11 springs; these species constitute $2.8 \%$ of the total flora.

The list of uncommon plants consists of 17 species: Arctium lappa L., Xanthium strumarium L., Capsella bursa-pastoris (L.) Medik., Chenopodium album L., Convulvus arvensis L., Poa annua L., Bromus squarrosus L. and Elytrigia repens (L.) Nevski, belonging to weeds; Typha angustifolia L., Phragmites australis (Cav.) Trin. ex Steud. and Scirpus lacustris L. comprising the coastal aquatic group; Crataegus ambigua C.A. Mey. ex A. Beck. (forest species), Rosa canina L. (forest glade species), Elaeagnus argentea Pursh (meadow and steppe species), Achillea millefolium L. (meadow species), Artemisia lercheana Web. (steppe and semi-arid species), Artemisia lessingiana Bess. (semi-arid species). These plants can be found on the territory of 5 to 7 springs, and account for $6.7 \%$ of all species of flora.

100 species, accounting for $39.7 \%$ of the total amount, can be considered rare and have found within the territory of 2 to 4 springs. Half of the species $(50.8 \% ; 128$ plants) were represented by single specimens (very rare) and were found on the territory of only one of the springs.

The studied floras were compared using the Jaccard index $(K j)$. The similarity matrices obtained via the ExStatR software were used in cluster analysis as a basis for constructing dendrograms of the similarity of the studied floras via UPGMA technique.

For the analyzed floras in pair wise comparison, $K j$ varies from 0.02 to 0.5 . Cluster analysis has identified several groups (Figure). A separate cluster represents the spring no. 16 - Karauylkeldy, where we found three unique species that were not found at the territories of any of the other springs.

The second cluster includes springs No. 17, 18, 19, and 28. The degree of similarity of species composition according to $K j$ varies from 0.05 to 0.11 . The flora of these spring tracts includes from 15 to 35 species and is characterized by a predominance of xerophytes. Common species for the flora of most springs are: Agropyron desertorum (Fisch. ex Link) Schult., Artemisia austriaca Jacq., Artemisia salsoloides Willd., Asparagus inderiensis Blum ex Pacz., Atriplex cana C.A. Mey, Halocnemum strobilaceum (Pall.) Bieb., Spiraea crenata L.

The third cluster of springs is divided into two subordinate clusters. One such sub cluster consists of 10 springs: no. 9, 20, 21, 22, 24, 26, 25, 27, 29, and 30. The degree of similarity according to $K j$ varies from 0.13 to 0.4 . The flora of these springs is not very diverse (it is comprised from 3 to 10 species). Xeromesophyte and mesoxerophyte are dominant and the following species are common for all floras: Taraxacum officinale Wigg. (found within the flora of almost all springs from this group), Polygonum aviculare L., Capsella bursa-pastoris (L.) Medik. and Bromus squarrosus L. The other sub 
cluster consists of 11 springs: No. 39, 40, 6, 8, 15, 32, 35, 34, 33, 36, and 38. The flora of these spring tracts consists of 3 to 10 species. The degree of similarity in $K j$ varies from 0.12 to 0.5 . The common species for five spring tracts is a xeromesophyte, Polygonum aviculare L.; a xerophyte, Plantago lanceolata L. is common for four springs while xerophytes Lappula squarrosa (Retz.) Dumort. and Artemisia lercheana Web are common for three springs. Common species for only two spring tracts are: a mesophyte, Arctium lappa L.; mesohygrophytes Atriplex micrantha C. A. Mey., Mentha arvensis L., Mentha longifolia (L.) Huds; a mesoxerophyte, Chenopodium album L.; a xeromesophyte, Elaeagnus argentea Pursh; ultrahygrophytes Phragmites australis (Cav.) Trin. ex Steud., Scirpus lacustris L., Sium latifolium L.; a hygrohmesophyte, Urtica dioica L.

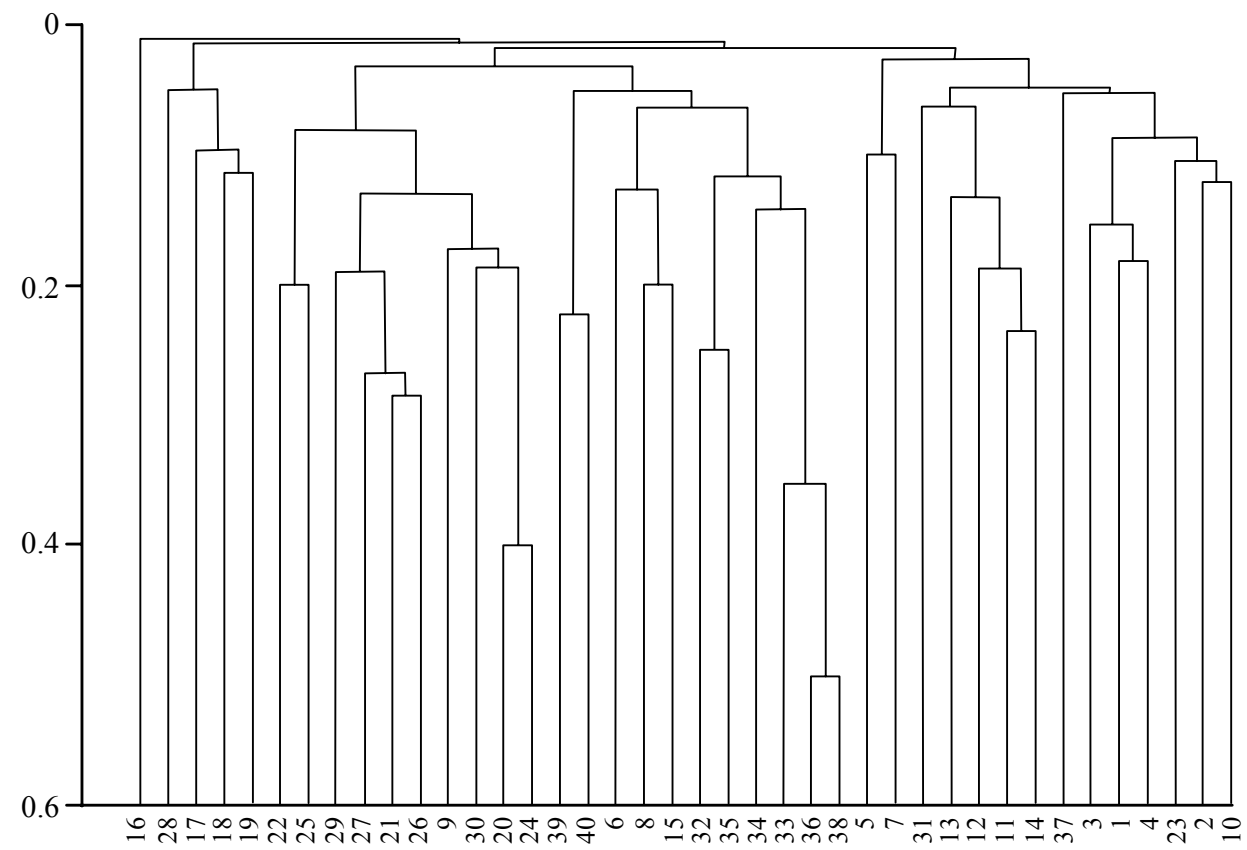

Figure. Dendrogram of similarity of species composition for the flora of territories adjacent to springs on the basis of calculated values of the Jaccard index $(K j)$

The fourth cluster is represented by 14 springs: no. 5, 7, 31, 13, 12, 11, 14, 37, 3, 1, $4,23,2$, and 10. The degree of similarity in $K j$ varies from 0.05 to 0.24 . The flora of the territories of these springs was quite heterogeneous and contains from 4 to 58 species. This cluster was characterized by mesophytic species. The most common species was a mesophyte Tripleurospermum perforatum (Merat) M. Lainz, found on the territory of eight spring tracts. Other common species for the territories of seven springs include a mesophyte, Trifolium pratense L., while a mesophyte Plantago major L was found at six different springs. In addition, the following common species were observed at the territories of five spring tracts: a xeromesopyte, Achillea millefolium L., a mesophyte, Arctium 


\section{BIOECOLOGICAL CHARACTERISTICS OF THE FLORA}

lappa L., a mesoxerophyte, Convulvus arvensis L., and a mesophytePoa annua L., while a mesophyte, Betula pendula Roth, a mesohyhgrophyte, Populus tremula L., xeromesophytesRosa canina L., and Thymus serpyllum L., a hygromesophyte Urtica urens L. and a mesophyte, Euphorbia virgata Waldst. \& Kit. were common for four spring tracts.

Thus, cluster analysis confirmed the extreme heterogeneity of species composition.

\section{CONCLUSION}

The flora of the territories adjacent to the spring outlets is represented by 252 species, 167 genera and 55 families belonging to Equisetophyta, Pinophyta and Magnoliophyta families. The Asteraceae and Poaceae families are dominant. There are 20 rare and protected species of plants listed in the Red Books of the Russian Federation and the Republic of Kazakhstan. The basis of the flora of spring tracts is perennial herbaceous plants (154 species), including long-rooted, rod-rooted and short-rooted grasses. There are 4 main types of geoelements - Eurasian, Holarctic and pluriregional. According to ecological analysis of the flora, 1) the largest number of species (73) among cenomorphs belong to 2 groups - steppe plants and weeds; 2) xerophytes, mesophytes and xeromesophytes are dominant hydromorphic types; 3 ) based on the soil nutrient status, the majority of species are mesotrophic. The flora of the territories contain representatives of halophytic, - psammophyte and calciphilous groups. Of the flora, 7 species are common, 17 are uncommon, 100 are rare and 128 are very rare. For the analyzed floras in pairwise comparison, $K j$ varies from 0.02 to 0.5 . Cluster analysis confirmed the extreme heterogeneity of species composition and low degree of similarity of flora.

\section{REFERENCES}

Akhmedenov K. M. Spring Landscapes of Western Kazakhstan. Uralsk, NIDS Publ., 2015, vol. 1.131 p. (in Russian).

Akhmedenov K. M., Petrishchev V. P., Golovachev I. V., Bakiev A. G., Gorelov R. A., Kalmykova O. G., Maikanov N. S. Indersk Salt Dome Landscape - a Preserved Pearl of Western Kazakhstan. Uralsk, Zhangir Khan West Kazakhstan Agrarian and Technical University Publ., 2017. 142 p. (in Russian).

Cherepanov S. K. Vascular Plants of Russia and Adjacent States (the former USSR). Saint Petersburg, Mir i sem'ya Publ., 1995. 992 p. (in Russian).

Darbaeva T. E., Chukalina O. N. Catalogue of Plants of West Kazakhstan Region. Uralsk, Seytzhanova Zh. D. Publ., 2011. 288 p. (in Russian).

Davidenko T. N. Recreational potential of plant communities in the vicinity of the Denezhniy spring in the Saratov. The New Science: the Current State and Development Trends, 2016, no. 9, pp. 4-7 (in Russian).

Fensham R. J. Mound springs in the Dawson River Valley, Queensland. Vegetation - Environment Relations and Consequences of a Proposed Impoundment on Botanical Values. J. Pacific Conservation Biology, 1998, vol. 4, pp. 42-54.

Fensham R. J., Fairfax R. J. Spring wetlands of the Great Artesian Basin, Queensland, Australia. J. Wetlands Ecology and Management, 2003, vol. 11, iss. 5, pp. 343-362.

Idrisova G. Z., Sergeeva I. V., Shevchenko E. N., Ponomareva A. L. Rare and protected plant species of springs of Western Kazakhstan. Bulletin of the Botany Garden of Saratov State University, 2018, vol. 16, no. 2, pp. 66-71 (in Russian). 
G. Z. Idrissova, I. V. Sergeeva, E. N. Shevchenko et al.

Mamysheva M. V., Darbaeva T. E. Rare plants of plant communities of Bolshaya Ichka mountain within the West Kazakhstan region. Izvestia of Samara Scientific Center of the Russian Academy of Sciences, 2012, vol. 14, no. 1, pp. 1776-1779 (in Russian).

Matveev N. M. Bioecological Analysis of Flora and Vegetation (on the example of foreststeppe and steppe zones): workbook. Samara, Samarskii universitet Publ., 2006. 311 p. (in Russian).

Mayevsky P. F. Flora of the Middle Zone of the European Part of the USSR. Leningrad, Kolos Publ., 1964. 879 p. (in Russian).

Mayevsky P. F. Flora of the Middle Zone of the European Part of Russia. 10th ed. Moscow, KMK Scientific Press Ltd., 2006. 600 p. (in Russian).

Myrzagalieva Zh. Zh., Stanis E. V. Rare species of plants within the specially protected natural territories of the steppe ecosystem of the West Kazakhstan region. International Scientific Research J., 2016, no. 5, pp. 85-87 (in Russian).

Plaksina T. I. Synopsis of Flora of the Volga-Ural Region. Samara, Samarskii universitet Publ., 2001. 388 p. (in Russian).

Ponder W. F. Desert Springs of the Australian Great Artesian Basin. In: D. W. Sada, S. E. Sharpe, eds. Conference Proceedings. Spring-fed Wetlands: Important Scientific and Cultural Resources of the Intermountain Region. Las Vegas, 2002, pp. 1-13.

Raunkiaer C. The Life Forms of Plants and Statistical Plant Geography. Oxford, Clarendon Press, 1934. $632 \mathrm{p}$.

Red Book of Kazakhstan. Astana, Bagira Ltd., 2006. 550 p.

Red Book of the Russian Federation (Plants and Mushrooms). Moscow, KMK Scientific Press Ltd., 2008. 855 p. (in Russian).

Rosenau J. C., Faulkner G. L., Hendry C. W., Hull R. W. Springs of Florida. Florida Bureau of Geology Bulletin, 1977, no. 31. 461 p.

Serebryakov I. G. Ecological Morphology of Plants. Moscow, Nauka Publ., 1962. 378 p. (in Russian).

Serebryakov I. G. Life Forms of Plants and Their Study. Field Geobotany. Moscow, Nauka Publ., 1964, vol. 3, pp. 146-205 (in Russian).

Sinitsyna M. V. Ekologo-biologicheskie osobennosti flory malykh iskusstvennykh vodoemov Saratovskoi oblasti [Ecological and Biological Features of the Flora of Small Artificial Reservoirs of the Saratov Region]. Diss. Cand. Sci. (Biol.). Saratov, 2013. 166 p. (in Russian).

Sivohip Zh. T., Kalmykova O. G. Landscape-ecological features of hydromorphic complexes of "Orenburg" gas processing plant. Vestnik of the Orenburg State University, 2007, spec. iss., pp. 55-59 (in Russian).

Skvortsov A. K. Herbarium. Manual on Methods and Techniques. Moscow, Nauka Publ., 1977. 199 p. (in Russian).

Takhtadzhyan A. L. The Floristic Regions of the World. Leningrad, Nauka Publ., 1978, 247 p. (in Russian).

Tolmachev A. I. An Introduction to the Geography of Plants. Leningrad, Izdatel'stvo Leningradskogo universiteta, 1974. 244 p. (in Russian).

Tolmachev A. I. Methods of Comparative Floristics and Problems of Florogenesis. Novosibirsk, Nauka Publ., 1986. 195 p. (in Russian).

Zhantasova G. M., Akhmedenov K. M. Complex assessment of the state of spring tracts "Aksu" and "Akbulak" of West Kazakhstan region. Steppes of Northern Eurasia: Proceedings of the VIth International Simposium and VIIIth International School and Workshop "Geoenvironmental Problems of the Steppe Regions". Orenburg, Gazprompechat Publ., 2012, pp. 261-264 (in Russian). 
УДК 581.93:627.12(574.1)

\title{
БИОЭКОЛОГИЧЕСКАЯ ХАРАКТЕРИСТИКА ФЛОРЫ ТЕРРИТОРИЙ, ПРИМЫКАЮЩИХ К РОДНИКАМ ЗАПАДНОГО КАЗАХСТАНА
}

\author{
Г. З. Идрисова ${ }^{1}$, И. В. Сергеева ${ }^{2}$, Е. Н. Шевченко ${ }^{2}$, \\ А. Л. Пономарева ${ }^{2}$, К. М. Ахмеденов ${ }^{3}$ \\ ${ }^{1}$ Западно-Казахстанский аграрно-технический университет имени Жангир хана \\ Казахстан, 090009, Уральск, Жангир хана, 51 \\ ${ }^{2}$ Саратовский государственный аграрный университет имени Н. И. Вавилова \\ Россия, 410012, Саратов, Театральная пл., 1 \\ 3 Западно-Казахстанский государственный университет имени Махамбета Утемисова \\ Казахстан, 090009, Уральск, просп. Н. Назарбаев, 162 \\ E-mail:en-shevchenko@mail.ru
}

Поступила в редакцию 22.12.2018 г., после доработки 18.03.2019 г., принята 11.05.2019 г.

Idrissova G. Z., Sergeeva I. V., Shevchenko E. N., Ponomareva A. L., Akhmedenov K. M. Bioecological Characteristics of the Flora of the Territories Adjacent to the Springs of Western Kazakhstan [Идрисова Г. З., Сергеева И. В., Шевченко Е. Н., Пономарева А. Л., Ахмеденов К. М. Биоэкологическая характеристика флоры территорий, примыкающих к родникам Западного Казахстана] // Поволжский экологический журнал. 2019. № 4. C. 419 - 431. DOI: https: https://doi.org/10.35885/1684-7318-2019-4-419-431

Приведены данные флористических исследований 40 родниковых урочищ Мангистауской, Актюбинской, Атырауской и Западно-Казахстанской областей западного региона Республики Казахстан. Выявлено, что изученная флора представлена 252 видами, 167 родами и 55 семействами, относящимися к Отделам Equisetophyta, Pinophyta и Magnoliophyta. Дана таксономическая характеристика флоры, показавшая доминирование семейств Asteraceae и Роaceae. Во флоре родниковых урочищ определено преобладание многолетних травянистых растений по системе жизненных форм И. Г. Серебрякова. Выявлено преобладание степных и сорных растений. Хорологический анализ показал ведущую совокупность видов с евроазиатским типом ареала. Экологическая характеристика выделила доминирование ксерофитов и мезотрофов. Выявлено 20 охраняемых видов растений, занесенных в Красную книгу Российской Федерации и Красную книгу Республики Казахстан. Анализ распространения растений на территориях, примыкающих к родникам, определил четыре градации встречаемости: часто - 7 видов, нечасто - 17 , редко 100 и очень редко - 128. Наиболее часто встречающимися на территориях родниковых урочищ являются виды, относящиеся к сорным растениям: Tripleurospermum perforatum (Merat) M. Lainz, Polygonum aviculare L., Taraxacum officinale Wigg., Lappula squarrosa (Retz.) Dumort., Plantago major L., Arctium lappa L., Xanthium strumarium L., Capsella bursa-pastoris (L.) Medik., Chenopodium album L., Convulvus arvensis L., Poа аппиа L., Bromus squarrosus L., Elytrigia repens (L.) Nevski. Для анализируемых флор в попарном сравнении коэффициента Жаккара $(K j)$ варьирует от 0.02 до 0.5 , что показывает чрезвычайную разнородность видового состава.

Ключевые слова: флора, родники, урочище, биоморфологическая и экологическая характеристики, Западный Казахстан.

DOI: https://doi.org/10.35885/1684-7318-2019-4-419-431 